\title{
Early detections of SARS-CoV-2 in wastewater and their use in COVID-19
}

\section{epidemiological control}

\author{
Detecções precoces do SARS-CoV-2 em águas residuais e seu uso no controle epidemiológico do
}

COVID-19

La detección precoz de SARS-CoV-2 en las aguas residuales y su uso en el control epidemiológico

de COVID-19

Received: 04/19/2021 | Reviewed: 04/26/2021 | Accept: 04/28/2021 | Published: 05/12/2021

Pedro Henrique Mainardi

ORCID: https://orcid.org/0000-0003-0234-0052 Universidade Estadual Paulista "Júlio de Mesquita Filho", Brazil

E-mail: pedro.h.mainardi@unesp.br

Ederio Dino Bidoia

ORCID: https://orcid.org/0000-0001-7040-1983 Universidade Estadual Paulista "Júlio de Mesquita Filho", Brazil

E-mail: ederio.bidoia@unesp.br

\begin{abstract}
SARS-CoV-2 is a new type of coronavirus that is capable to infect humans and cause the severe acute respiratory syndrome COVID-19, a disease that has been causing enormous impacts across the whole Earth. COVID-19 patients, including mild, pre-symptomatic and asymptomatic cases, were often seen to contain infectious fragments of SARSCoV-2 in urine and feces samples. Thus, studies to detect the new coronavirus in wastewater, which collect and concentrate human excreta, have been extremely useful as a tool to monitor the virus spread in the communities. The surveillance, frequently used to elaborate economical non-invasive diagnoses about the circulation of chemicals and pollutants in populations, could be used as a quick alert about emerging and reemerging COVID-19 epidemics, improve the predictions concerning the SARS-CoV-2 dissemination and promote the development of better viral containment measures. Along that, the approach could be used to construct more accurately epidemiological models, foment better practices to coordinate resources an administer the vaccines, assess the propagation of SARS-CoV-2 variants across temporal and geographic scales, evaluate environmental risks and also the effectiveness of disinfection systems. In this review, it was addressed early reports regarding SARS-CoV-2 detections in wastewater and the importance of this valuable approach in the application of faster and more effective interventions from public health authorities, either towards the COVID-19 or any other epidemic disease in the future.
\end{abstract}

Keywords: Epidemiology; Epidemiological monitoring; WBE; Collective health; Preventive medicine; Epidemiological surveillance.

\section{Resumo}

O SARS-CoV-2 é um novo tipo de coronavírus capaz de infectar humanos e causar a síndrome respiratória aguda grave COVID-19, doença que vem causando enormes impactos em todo o planeta Terra. Pacientes com COVID-19, incluindo casos leves, pré-sintomáticos e assintomáticos, frequentemente foram vistos por conter em amostras de urina e fezes fragmentos infecciosos do SARS-CoV-2. Sendo assim, estudos para detectar o novo coronavírus em águas residuárias, que coletam e concentram os excrementos humanos, têm sido extremamente úteis como uma ferramenta para monitorar a disseminação do vírus nas comunidades. A vigilância, frequentemente utilizada para elaborar diagnósticos econômicos e não invasivos sobre a circulação de produtos químicos e poluentes nas populações, poderia ser utilizada como um alerta rápido sobre epidemias emergentes e reemergentes de COVID-19, melhorar as previsões acerca da propagação do SARS-CoV-2 e promover o desenvolvimento de melhores medidas de contenção viral. Além disso, a abordagem poderia ser utilizada para construir modelos epidemiológicos com maior precisão, fomentar melhores práticas para coordenar recursos e administrar as vacinas, avaliar a propagação de variantes do SARS-CoV-2 em escalas temporais e geográficas, avaliar riscos ambientais e também a eficácia dos sistemas de desinfecção. Nesta revisão, foram abordados os relatos precoces de detecção do SARS-CoV-2 em águas residuais e a importância dessa valiosa abordagem na aplicação de intervenções mais rápidas e eficazes por parte das autoridades de saúde pública, seja em relação à COVID-19 ou qualquer outra doença epidêmica no futuro.

Palavras-chave: Epidemiologia; Monitoramento epidemiológico; EBAR; Saúde coletiva; Medicina preventiva; Vigilância epidemiológica. 


\begin{abstract}
Resumen
El SARS-CoV-2 es un nuevo tipo de coronavirus capaz de infectar a los humanos y causar el síndrome respiratorio agudo severo COVID-19, una enfermedad que ha estado causando grandes impactos en todo el mundo. A menudo se ha observado que los pacientes con COVID-19, incluidos los casos leves, presintomáticos y asintomáticos, contienen fragmentos infecciosos de SARS-CoV-2 en muestras de heces y orina. Así, los estudios para detectar el nuevo coronavirus en las aguas residuales, que recolectan y concentran excrementos humanos, han sido de gran utilidad como herramienta para monitorear la diseminación del virus en las comunidades. La vigilancia, que a menudo se utiliza para desarrollar diagnósticos económicos y no invasivos sobre la circulación de sustancias químicas y contaminantes en las poblaciones, podría usarse como una alerta rápida sobre epidemias emergentes y reemergentes de COVID-19, mejorando las predicciones sobre la propagación del SARS-CoV-2 y promover el desarrollo de mejores medidas de contención viral. Además, el enfoque podría usarse para construir modelos epidemiológicos con mayor precisión, fomentar las mejores prácticas para la coordinación de recursos y la administración de vacunas, evaluar la propagación de las variantes del SARS-CoV-2 en escalas temporales y geográficas, evaluar los riesgos ambientales y también la efectividad de sistemas de desinfección. En esta revisión, discutimos los informes de detección precoz de SARS-CoV-2 en aguas residuales y la importancia de este valioso enfoque en la aplicación de intervenciones más rápidas y efectivas por parte de las autoridades de salud pública, ya sea en relación con COVID-19 o cualquier otro enfermedad epidémica en el futuro.
\end{abstract}

Palabras clave: Epidemiología; Monitoreo epidemiológico; EBAR; Salud pública; Medicina Preventiva; Vigilancia epidemiológica.

\title{
1. Introduction
}

SARS-CoV-2 is a human infective novel coronavirus that is responsible to cause the severe acute respiratory syndrome disease COVID-19 ( $\mathrm{Zu}$ et al. 2020). Although a controversial origin, the enveloped single-stranded RNA SARSCoV-2 virus (Figure 1), which phylogenetically belongs to the Betacoronavirus genera and Sarbecovirus subgenus, was first detected in late December of 2019 at the city of Wuhan, in China (Andersen et al. 2020; Hua \& Shaw 2020). The rapid spread, along a high fatality rate due to serious infections caused in the human respiratory system, has made the disease a major worldwide health problem (Grunig et al. 2020). The COVID-19 disease was considered a global health emergency by the World Health Organization in late January 2020 and, in March 2020, acquired pandemic proportions (WHO 2020a). According to the agency, on March 24 of 2021, there was 223 countries, areas or territories affected by the COVID-19, approximately 126 359540 confirmed cases and 2769473 fatalities (WHO 2020b).

Figure 1. Transmission electron micrograph of SARS-CoV-2 particles isolated from a patient.
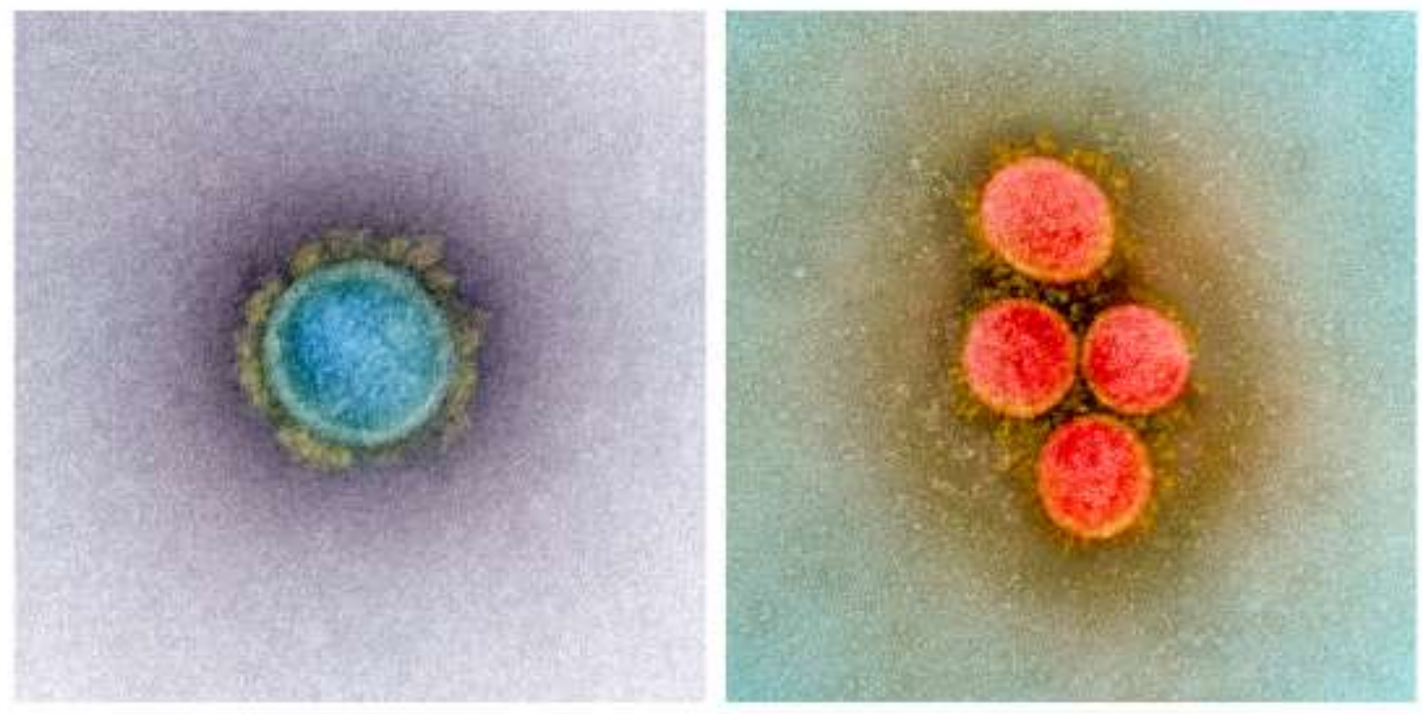

Note that the spike glycoproteins, crown-like structures that derived its name ("corona" is the Latin word for crown), can be observed on the surface of the viral envelope. Source: NIAID-RML. 
COVID-19 disease, according to reports, was seen to cause manifestations on several human systems, including the neurological, cardiovascular, visual, renal, immune, musculoskeletal and gastrointestinal ones (Borsa \& Mazet 2020; Chen et al. 2020; Cipollaro et al. 2020; Diao et al. 2020; Guo et al. 2020; Jin et al. 2020; Pezzini \& Padovani 2020). Symptomatic patients generally had their respiratory system affected, with clinical symptoms such as taste and smell dysfunctions, fever, dry cough, fatigue, rhinorrhea, dyspnea, lethargy, muscle pain, headache, diarrhea, vomiting and, in some cases, severe pneumonia (Eliezer et al. 2020; Sun et al. 2020; Xu et al. 2020; Yang et al. 2020).

SARS-CoV-2 is transmitted through the direct contact with secretions, such as saliva, respiratory droplets and aerosols particles that are carried and dispersed by the air (Morawska \& Cao 2020; Setti et al. 2020). The transmission may also occur by indirect contact through contaminated surfaces and fomites (Mouchtouri et al. 2020; Patel et al. 2020; Xie et al. 2020). The transmission of the disease has been limited by protective measures, such as personal hygiene, use of face masks, eye protectors, physical distancing, adequate ventilation of closed spaces, surface disinfections and immunization by vaccines (Amanat \& Krammer 2020; Chu et al. 2020; Sah et al. 2020; WHO 2020c; Ding et al. 2021).

COVID-19 patients, including pre-symptomatic, asymptomatic and mild cases were frequently seen to contain fragments of SARS-CoV-2 in feces and urine samples (Furukawa et al. 2020; Jeong et al. 2020; Jiang et al. 2020; Li et al. 2020; Park et al. 2020; Wei 2020). The fragments, usually SARS-CoV-2 genome particles detected by molecular biology methods, have presumed an active viral replication in those environments (Khan et al. 2020; Qian et al. 2020). The presence of SARS-CoV-2 fragments in those samples, infectious in some cases, has also evidenced the possibility of the viral transmission through the direct contact or by the aerosols generated by feces and urine of infected patients (Jeong et al. 2020; Kang et al. 2020; Kashi et al. 2020; Patel 2020; Xiao et al. 2020; Elsamadony et al. 2021). The occurrence of viral fragments in those samples, as addressed in this literature review, has also brought the importance of the detection and the monitoring of the SARS-CoV-2 in wastewater.

\section{Methodology}

The systematic literature review was written based on articles published in the Google Scholar, PubMed, Scopus, ScienceDirect, Web of Science and MedRxiv databases. The terms used in the searches were "SARS-CoV-2", "detection" or "early detection", "wastewater" or "sewage", and "wastewater-based epidemiology". The surveys were carried out until 1st of April of 2021 and included both public open-access and institutional available articles published in English.

\section{Epidemiological Surveillance in Wastewater}

Monitoring investigations proceeded in wastewater, which is known to gather and concentrate human excretions, have relied on the hypothesis that excreted substances by humans are stable in wastewater and could be used to estimate the original excreted concentration by the serviced population (Polo et al. 2020). The non-invasive approach, named Wastewater-Based Epidemiology (WBE), has been frequently used a fast and low-cost diagnose to generate real time information regarding the behavior and the circulation dynamics of pollutants, chemicals and also pathogens in communities (Figure 2) (Choi et al. 2018; Daughton 2018; Sims \& Kasprzyk-Hordern 2020).

When focused on the detection of viral pathogens, such as SARS-CoV-2, surveillance in wastewater has the potential to vastly contribute to assess and preserve the health condition of a population. The approach has been considered as a noninvasive, economical, fast and robust form of viral monitoring and COVID-19 epidemiological control (Messina 2020; Thompson et al. 2020; Mainardi \& Bidoia 2021). The SARS-CoV-2 surveillance in wastewater, as described in the next section, could provide better forecasts about the COVID-19 spread in the communities. The monitoring could be used to 
generate quick alerts about possible emerging and reemerging COVID-19 outbreaks and promote the application of better measurements to contain the viral propagation (Bogler et al. 2020; Mao et al. 2020a; Orive et al. 2020).

Figure 2. Schematic diagram of the Wastewater-Based Epidemiology as a surveillance strategy.

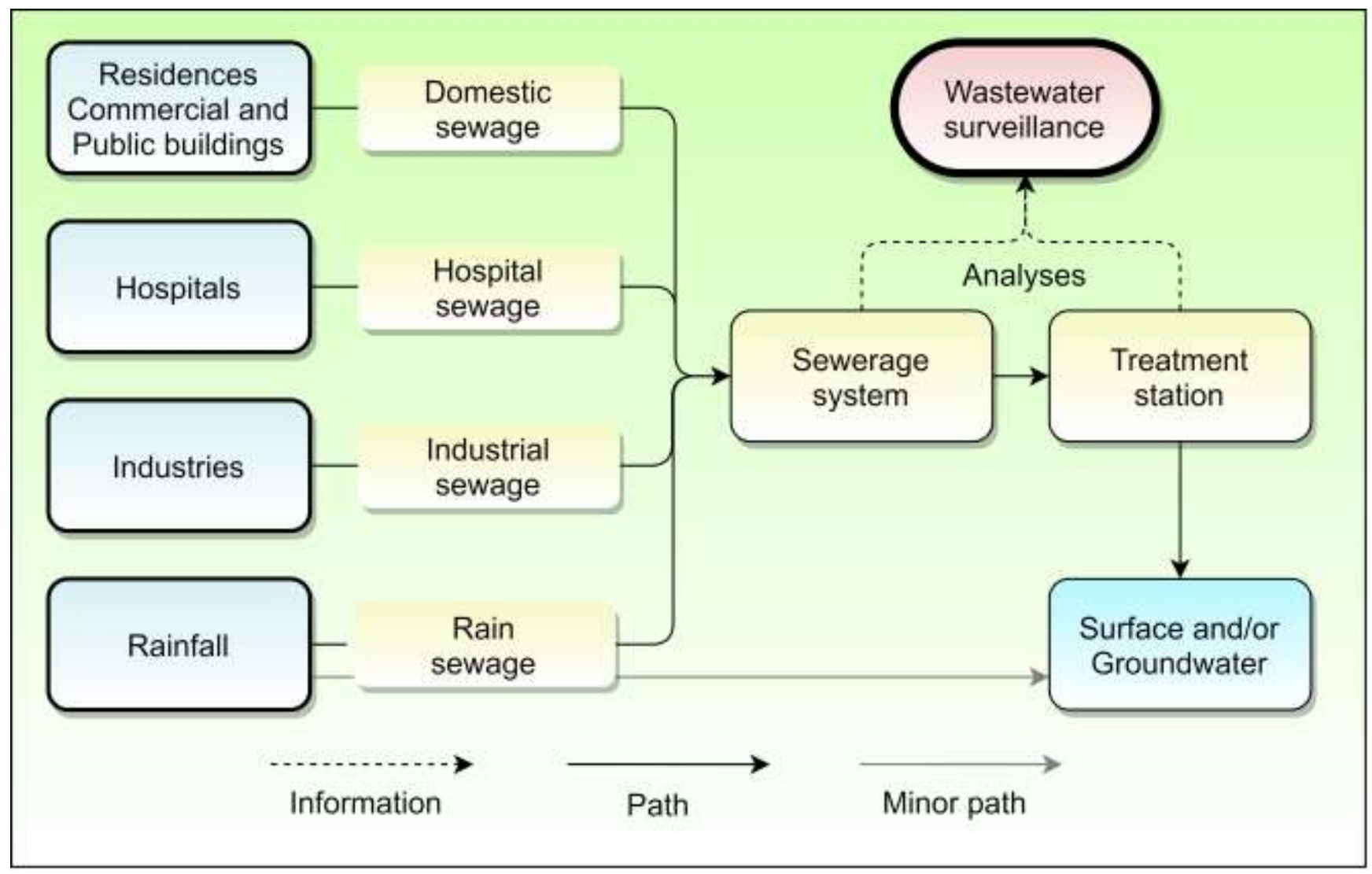

Note that most of the excretes are collected and concentrated in the sewerage system and in the treatment station. Source: Authors.

\section{Early Detections of SARS-CoV-2 in Wastewater}

The first report of a SARS-CoV-2 detection in wastewater was done by Medema et al. (2020a), who detected the new coronavirus in wastewaters samples that were collected in March 4 of 2020 in the Netherlands. According to the author, the presence of the new coronavirus was detected nearly one week after the first official case reported in the country and six days before the first COVID-19 reported case in the studied city of Amersfoort, Utrecht. Martin et al. (2020), in turn, detected the new coronavirus in wastewater samples that were collected three days before the first official report of COVID-19 in the sewage plant catchment area of South East Region, England.

Peccia et al. (2020), studying primary clarification sludge of a wastewater treatment plant in the metropolitan area of New Haven, Connecticut, detected SARS-COV-2 viral particles one to four days before hospital admissions and six to eight days before positive test results conducted in the studied placement. Sensitivity analysis proceeded by Kaplan et al. (2020), that included alternative lag distributions from infection until hospitalization in that area, suggested that viral particles of SARSCoV-2 could be detected in the sewage sludge before of an average period of three to five days before the admissions in the local hospital.

D'Aoust et al. (2021), investigating primary clarified sludge samples obtained in the treatment plant of the city of Ottawa, identified an increase in the SARS-CoV-2 viral signals in wastewater 48 hours before positive COVID-19 clinical tests and 96 hours before local hospitalizations. Kumar et al. (2021) also observed a change on the SARS-CoV-2 genome 
particles concentration in wastewater samples collected one to two weeks before official clinical cases in the studied location of Gandhinagar, Gujarat, India. Randazzo et al. (2020), as well, detected the new corona virus in wastewater samples collected in the municipalities of Lorca, Cieza and Totana 12 to 16 days before the local official reports of COVID-19 cases.

Researchers by Melvin et al. (2021) indicated that, in both rural and in large metropolitan areas of Minnesota, wastewater monitoring could presage changes in new local clinical cases by as much as two weeks (15 to 17 days) in advance. Saguti et al. (2021) also evidenced that SARS-CoV-2 genomes variations in wastewater samples collected in Gothenburg, Sweden, preceded the variations of newly local hospitalized patients in 19 to 21 days. Stadler et al. (2020), in turn, evidenced that levels of SARS-CoV-2 signals in wastewater samples collected in the metropolis of Houston, Texas, were a strong predictive indicator of trends in the local nasal positivity cases around two-weeks in advance.

Early detections of SARS-CoV-2 in wastewater were also reported by Ahmed et al. (2021), who identified viral signals of the new coronavirus in wastewaters collected in Brisbane South, Australia, three weeks before the first clinical case reported the sewerage catchment area. Moreover, Karthikeyan et al. (2021) also evidenced the prediction of new reported cases up to three weeks in advance through the use of an autoregressive integrated moving average model on wastewater samples collected at San Diego, California.

The detection of SARS-CoV-2 genome particles in wastewater, as well, was shown to be able to predict COVID-19 cases in country-wide scales. According to Chavarria-Miró et al. (2020), SARS-CoV-2 signals were detected in archived wastewaters samples that were collected in March 12 of 2019 in Spain, nearly one year before the first official COVID-19 case reported in the country. Fongaro et al. (2021) also stated the presence of the SARS-CoV-2 particles in archived wastewater samples collected in November 27 of 2019 in Brazil, approximately three months before the first official COVID-19 reported case in the country.

La Rosa et al. (2021), moreover, detected the presence of SARS-COV-2 particles in wastewater samples collected in December 18 of 2019 in Italy, around one month before the first official COVID-19 case reported in the country. Jørgensen et al. (2020), then, also evidenced the presence of the new coronavirus genome particles in February 24 of 2020 in Denmark, around three days before the first official COVID-19 case in the country. Early local and country-wide detections of SARSCoV-2 in wastewater and sewage sludge was summarized in Table 1.

Table 1. Early detections of SARS-CoV-2 in liquid and solid phases of wastewater samples.

\begin{tabular}{|c|c|c|c|c|}
\hline Country & Location & Sample source & Signal detection & Reference \\
\hline Netherlands & Amersfoort, Utrecht & Sewage & $\begin{array}{l}1 \text { week after the first official COVID- } 19 \text { case } \\
\text { reported in the country and } 6 \text { days before the } \\
\text { first reported case in Amersfoort city }\end{array}$ & $\begin{array}{l}\text { Medema et al. } \\
\text { (2020a) }\end{array}$ \\
\hline $\begin{array}{l}\text { United } \\
\text { States }\end{array}$ & $\begin{array}{l}\text { New Haven, } \\
\text { Connecticut }\end{array}$ & $\begin{array}{l}\text { Primary sewage } \\
\text { sludge }\end{array}$ & $\begin{array}{l}\text { 1-4 days before local hospital admissions and } \\
6-8 \text { days before SARS-CoV-2 positive test } \\
\text { results }\end{array}$ & $\begin{array}{l}\text { Peccia et al. } \\
(2020)\end{array}$ \\
\hline Canada & Ottawa, Ontario & $\begin{array}{l}\text { Primary clarified } \\
\text { sludge }\end{array}$ & $\begin{array}{l}48 \text { hours before COVID-19 clinical tests and } \\
96 \text { hours before local hospitalizations }\end{array}$ & $\begin{array}{l}\text { D'Aoust et al. } \\
\text { (2021) }\end{array}$ \\
\hline England & South East Region & Wastewater & $\begin{array}{l}3 \text { days before the first reported case in the } \\
\text { sewage plant catchment area }\end{array}$ & $\begin{array}{l}\text { Martin et al. } \\
(2020)\end{array}$ \\
\hline $\begin{array}{l}\text { United } \\
\text { States }\end{array}$ & $\begin{array}{l}\text { New Haven, } \\
\text { Connecticut }\end{array}$ & Sewage sludge & $\begin{array}{l}\text { Average of } 3 \text { to } 5 \text { days before the admissions } \\
\text { in a local hospital }\end{array}$ & $\begin{array}{l}\text { Kaplan et al. } \\
(2020)\end{array}$ \\
\hline
\end{tabular}




\begin{tabular}{|c|c|c|c|c|}
\hline Country & Location & Sample source & Signal detection & Reference \\
\hline India & $\begin{array}{l}\text { Gandhinagar, } \\
\text { Gujarat }\end{array}$ & Wastewater & $\begin{array}{l}1-2 \text { weeks before the official clinical cases in } \\
\text { the studied location }\end{array}$ & $\begin{array}{l}\text { Kumar et al. } \\
\text { (2021) }\end{array}$ \\
\hline Spain & $\begin{array}{l}\text { Lorca, Cieza and } \\
\text { Totana } \\
\text { municipalities }\end{array}$ & Wastewater & $\begin{array}{l}12-16 \text { days before official COVID-19 cases in } \\
\text { the studied municipalities }\end{array}$ & $\begin{array}{l}\text { Randazzo et al. } \\
(2020)\end{array}$ \\
\hline $\begin{array}{l}\text { United } \\
\text { States }\end{array}$ & Minnesota & Wastewater & $\begin{array}{l}2 \text { weeks (15-17 days) before new clinical } \\
\text { cases in rural and large metropolitan areas }\end{array}$ & $\begin{array}{l}\text { Melvin et al. } \\
\text { (2021) }\end{array}$ \\
\hline Sweden & Gothenburg & Wastewater & $\begin{array}{l}\text { 19-21 days before new local hospitalized } \\
\text { patients }\end{array}$ & $\begin{array}{l}\text { Saguti et al. } \\
(2021)\end{array}$ \\
\hline $\begin{array}{l}\text { United } \\
\text { States }\end{array}$ & Houston, Texas & Wastewater & 2 weeks before positive cases of nasal tests & $\begin{array}{l}\text { Stadler et al. } \\
(2020)\end{array}$ \\
\hline Australia & Brisbane South & Wastewater & $\begin{array}{l}3 \text { weeks before the first clinical case reported } \\
\text { in sewerage catchment area }\end{array}$ & $\begin{array}{l}\text { Ahmed et al. } \\
\text { (2021) }\end{array}$ \\
\hline $\begin{array}{l}\text { United } \\
\text { States }\end{array}$ & $\begin{array}{l}\text { San Diego, } \\
\text { California }\end{array}$ & Wastewater & 3 weeks before local newly reported cases & $\begin{array}{l}\text { Karthikeyan et } \\
\text { al. (2021) }\end{array}$ \\
\hline Spain & Barcelona & Wastewater & $\begin{array}{l}\text { Nearly } 1 \text { year before the first official COVID- } \\
19 \text { case reported in the country }\end{array}$ & $\begin{array}{l}\text { Chavarria-Miró } \\
\text { et al. (2020) }\end{array}$ \\
\hline Brazil & $\begin{array}{l}\text { Florianópolis, Santa } \\
\text { Catalina }\end{array}$ & Sewage & $\begin{array}{l}\text { Nearly } 3 \text { months before the first official } \\
\text { COVID- } 19 \text { case reported in the country }\end{array}$ & $\begin{array}{l}\text { Fongaro et al. } \\
(2021)\end{array}$ \\
\hline Italy & $\begin{array}{l}\text { Milan, Lombardy } \\
\text { and Turin, Piedmont }\end{array}$ & Sewage & $\begin{array}{l}\text { Nearly } 1 \text { month before the first official } \\
\text { COVID-19 case reported in the country }\end{array}$ & $\begin{array}{l}\text { La Rosa et al. } \\
\text { (2021) }\end{array}$ \\
\hline Denmark & Solrød, Zealand & $\begin{array}{l}\text { Liquid and solid } \\
\text { phases of } \\
\text { wastewater }\end{array}$ & $\begin{array}{l}3 \text { days before the first official COVID-19 case } \\
\text { reported in the country }\end{array}$ & $\begin{array}{l}\text { Jørgensen et al. } \\
(2020)\end{array}$ \\
\hline
\end{tabular}

Source: Authors.

\section{Methods Used to Detect the SARS-CoV-2 in Wastewater}

The methods used to detect the SARS-CoV-2 in wastewater samples, in general, have been made through molecular biology procedures based on "Reverse Transcription followed by Real-Time Polymerase Chain Reaction" (RT-qPCR). The technique, which has enabled the copy and quantification of fragments of the virus' genetic material through in-vitro replications, has been considered as reliable, sensitive, highly specific and the "gold standard" in the detection of low amounts of genetic material in different types of matrices (Corpuz et al. 2020; Hamouda et al. 2021). Earlier studies indicated that RTqPCR methods were successfully able to determine the diversity and abundance of several viral pathogens in wastewater, including Adenovirus, Astrovirus, Enterovirus, Hepatitis A and E, Norovirus, Papillomavirus, Parechovirus, Polyomavirus, Rotavirus and Salivirus (O'Brien et al. 2017; Bisseux et al. 2018; Gyawali \& Hewitt 2018; Adineh et al. 2019; I. Ahmed et al. 2019; Randazzo et al. 2019).

RT-qPCR method uses specific gene sequences that detect and copy unique fragments of the SARS-CoV-2 viral genome in the reaction, named primers. In general, the oligonucleotide unique sequences have targeted the N, N1 and N2 nucleocapsid proteins, the RdRP viral RNA polymerase gene, the S spike protein gene and the E envelope protein gene 
(Corpuz et al. 2020; Foladori et al. 2020). Due to their quantitative characteristic, RT-qPCR reactions have been made through the use hybridization probes, which are DNA sequences marked with fluorescent dyes, e.g., carboxyrhodamine, 6carboxyfluorescein and tetrachlorofluorescein (Michael-Kordatou et al. 2020). According to Ahmed et al. (2020), RT-qPCR methods, depending on the degree of the epidemic, were able to detect concentrations of up to 19 copies of SARS-CoV-2 gene particles per $1.0 \mathrm{~L}$ of wastewater. The main structural targets of the primers used to detect SARS-CoV-2 in wastewater were illustrated on Figure 3.

Figure 3. Schematic representation of the main structural proteins used to detect the SARS-CoV-2 in wastewater.
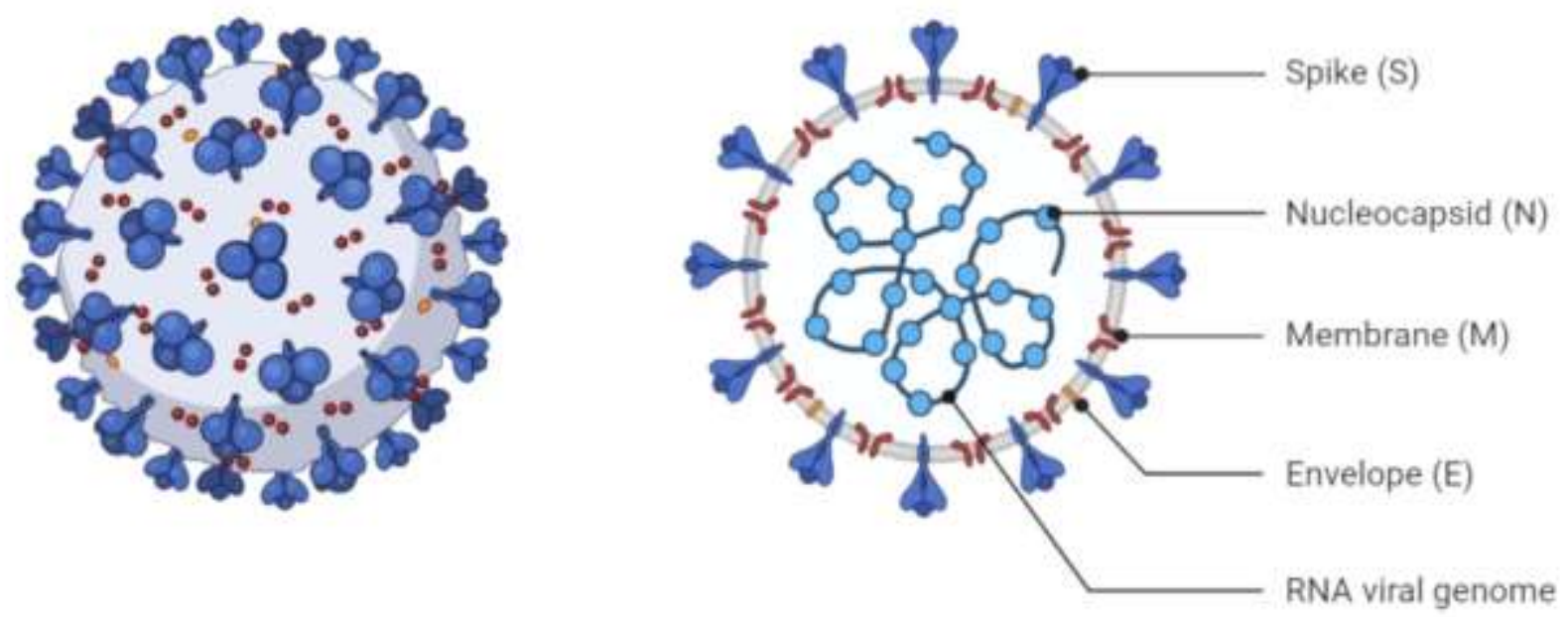

Note that the $\mathrm{S}$ spike protein, $\mathrm{N}$ nucleocapsid protein, $\mathrm{M}$ membrane protein, E envelope protein and the RNA viral genome were indicated in the illustration. Source: Created with BioRender.com.

\section{Wastewater Surveillance as a COVID-19 Epidemiological Control Approach}

Monitoring the SARS-CoV-2 in wastewaters, besides extremely useful as a non-evasive low-cost early alert about emerging and re-emerging outbreaks of COVID-19, would enable the enumeration of pre-symptomatic and asymptomatic cases, as well as people who do not have access to health care, which are frequently not detected by clinical diagnoses and may still spread the COVID-19 (La Rosa et al. 2020; Larsen \& Wigginton 2020; Lee et al. 2020; Lesimple et al. 2020). The approach, hence, would predict with more accuracy the real number of infected people with SARS-CoV-2 in specific communities and foment better practices to coordinate efforts, allocate healthcare resources and administer the vaccines (Curtis et al. 2020; Stadler et al. 2020; Vallejo et al. 2020; Pecson et al. 2021).

Wastewater monitoring could be used to assess the SARS-CoV-2 genetic diversity and detect viral variants that are circulating in the communities, including the more contagious and lethal B.1.1.7, B.1.351 and B.1.1.28 lineages (Jahn et al. 2021; Wurtzer et al. 2021; Yaniv et al. 2021). The strategy has been used to evaluate the dynamics of SARS-CoV-2 genomic alterations according to temporal and geographic scales and accurately infer their spread in populations (Izquierdo Lara et al. 2020; Kitajima et al. 2020; Nemudryi et al. 2020; Crits-Christoph et al. 2021; Pérez Cataluña et al. 2021). Viral diversity analyses in wastewater, moreover, could be applied in frozen and archived samples in order to promote future studies aimed at estimating the propagation and the SARS-CoV-2 ancestry (Dolfing et al. 2020).

SARS-CoV-2 surveillance in wastewaters has also been used to assess the environmental impacts and the public health risk associated with the viral transmissibility through water bodies, sewage, slurry, biosolids, aerosolized particles and/or animal hosts (Carducci et al. 2020; Fernández-de-Mera et al. 2020; Quilliam et al. 2020; Zhang et al. 2020a). The 
studies have been carried out to determine the efficiency of disinfection systems and foment strategies regarding the adequacy of water and wastewater treatment plants, waste transport and discharge procedures (Cahill \& Morris 2020; Zhang et al. 2020b; Patel et al. 2021). The researches have also aimed to analyze the safety of reused wastewaters in irrigation of food crops, groundwater recharge, cooling industrial processes and recreation porpoises (Ali et al. 2020; Bogler et al. 2020; Jha et al. 2020).

In order to improve, simplify and decrease the costs of SARS-CoV-2 detections on wastewater samples, economical, portable and fast detection devices based on isothermal amplification, paper-based biosensors, electrochemical immunosensors and microfluidic technologies have been increasingly investigated (Huang et al. 2020; Hui et al. 2020; Mao et al. 2020b; Giri et al. 2021; Lu et al. 2021). The devices, although under development, have aimed at promoting on-site analyses, which decreases the need of centralized laboratories, transport of material, expensive laboratory equipment, long-lasting assays and high skilled laboratory operators (Feng et al. 2020; Tymm et al. 2020; Patel et al. 2021). The approaches have been showing an enormous potential to generate near real time monitoring results and foment diagnosis with greater efficiency and practicality (Bhalla et al. 2020; Farkas et al. 2020). Potential uses of the Wastewater-Based Epidemiology approach were illustrated in Figure 4.

The detections efforts may support an international collaborative repository of SARS-CoV-2 surveillance in wastewater (https://www.covid19wbec.org/) (Bivins et al. 2020). The strategy could be used to improve the accuracy of wastewater surveillance methods and produce global comparable detection results (Michael-Kordatou et al. 2020; Nabi et al. 2020; Hamouda et al. 2021). Mostly, wastewater monitoring, along with other epidemiological models, such as serological data, rhinopharyngeal swabs diagnoses, clinical records and hospital admissions, has a great potential to be used to provide higher effectiveness of public health intervention (Kaplan et al. 2020; Medema et al. 2020b). The approach was shown to be a valuable tool for the authorities to assess and act quickly towards epidemic outbreaks, either on SARS-CoV-2 ones or other pathogen taxa in future events (Farkas et al. 2020; Daughton 2020; Weidhaas et al. 2021).

\section{Conclusion Remarks}

Due to the fact that patients with COVID-19, including mild, pre-symptomatic and asymptomatic cases were commonly seen to contain infectious fragments of SARS-CoV-2 in stool and urine samples, the detection of the new coronavirus in wastewaters, which collect and concentrate human excreta, has shown a great potential to be used as an epidemiological control tool. Through the approach, so called WBE, it would be possible generate rapid alerts about possible COVID-19 outbreaks and promote the development of better viral containment strategies and distributions of vaccines. The strategy also enables the quantification of health careless, pre and asymptomatic COVID-19 carriers, thus, could be used to construct more accurately epidemiological models and provide better predictions about the virus spread. SARS-CoV-2 monitoring in wastewaters, moreover, could be used to detect viral variants that are present in the populations and evaluate the efficacy of disinfection systems and treatment plants. The reliable, non-evasive and low-cost approach, along extremely useful for the authorities to rapidly intercede towards SARS-CoV-2 outbreaks, could be also used towards other pathogen taxa in the present or in the future. 
Figure 4. Potential uses of the Wastewater-Based Epidemiology approach.

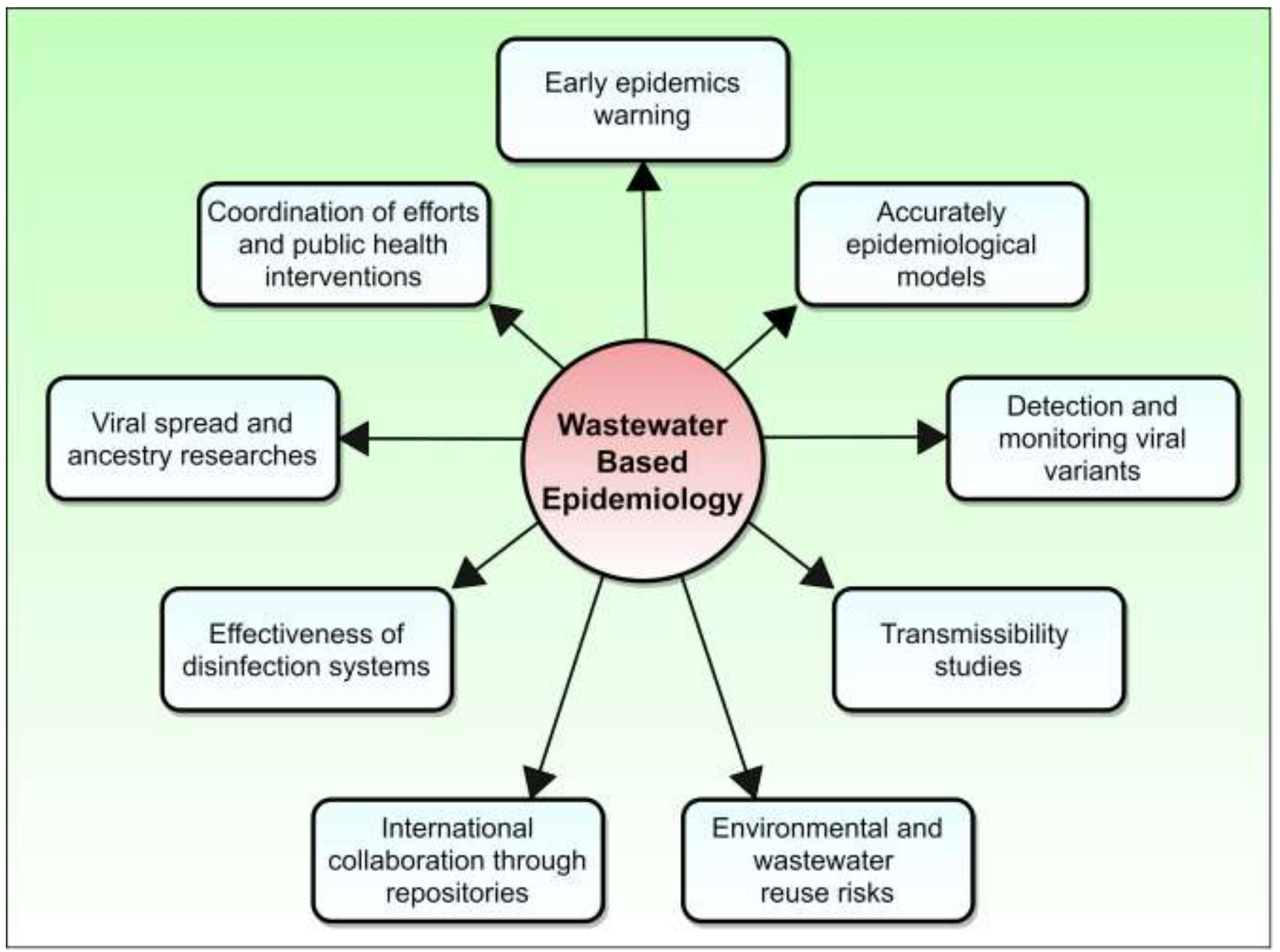

Note that the surveillance strategy can also be used to monitor the presence of chemical compounds, pollutants and other pathogens. Source: Authors.

Monitoring the SARS-CoV-2 in wastewater as a COVID-19 epidemiological surveillance tool, indeed, require the elaboration of standards and legislation based on scientific evidence, in addition to the adequacy of diagnostic infrastructures and the qualification of professionals engaged in monitoring. Practices focused at raising citizens' awareness and the readjustment of treatment plants for greater safety may also be widely required. Above all, considering the enormous harmful potential that pandemic diseases like COVID-19 can cause, greater investments in areas such as environmental monitoring, sanitation, water supply, as well as greater commitment from citizens and government agencies are utterly necessary.

\section{Acknowledgments}

This study was financed in part by the Coordenação de Aperfeiçoamento de Pessoal de Nível Superior - Brasil (CAPES) - Finance Code 001. The authors P.H.M. and E.D.B. thank CAPES and UNESP for the financial assistance and support. P.H.M. thanks C.M., G.M., C.T.M. and J.F.M. for the fundamental collaboration. The authors declare that they have no known conflict of interest.

\section{References}

Adineh, M., Ghaderi, M., \& Mousavi-Nasab, S. D. (2019). Occurrence of salivirus in sewage and river water samples in karaj, iran. Food and Environmental Virology, 11(2), 193-197. https://doi.org/10.1007/s12560-019-09377-1 
Ahmed, W., Angel, N., Edson, J., Bibby, K., Bivins, A., O’Brien, J. W., Choi, P. M., Kitajima, M., Simpson, S. L., Li, J., Tscharke, B., Verhagen, R., Smith, W. J. M., Zaugg, J., Dierens, L., Hugenholtz, P., Thomas, K. V., \& Mueller, J. F. (2020). First confirmed detection of SARS-CoV-2 in untreated wastewater in Australia: A proof of concept for the wastewater surveillance of COVID-19 in the community. Science of The Total Environment, 728 , 138764 . https://doi.org/10.1016/j.scitotenv.2020.138764

Ahmed, W., Tscharke, B., Bertsch, P. M., Bibby, K., Bivins, A., Choi, P., Clarke, L., Dwyer, J., Edson, J., Nguyen, T. M. H., O’Brien, J. W., Simpson, S. L., Sherman, P., Thomas, K. V., Verhagen, R., Zaugg, J., \& Mueller, J. F. (2021). SARS-CoV-2 RNA monitoring in wastewater as a potential early warning system for COVID-19 transmission in the community: A temporal case study. Science of The Total Environment, 761 , 144216. https://doi.org/10.1016/j.scitotenv.2020.144216

Ali, H. A., Yaniv, K., Bar-Zeev, E., Chaudhury, S., Shaga, M., Lakkakula, S., Ronen, Z., Kushmaro, A., \& Nir, O. (2020). Tracking SARS-CoV-2 RNA through the wastewater treatment process. MedRxiv, 2020.10.14.20212837. https://doi.org/10.1101/2020.10.14.20212837

Amanat, F., \& Krammer, F. (2020). Sars-cov-2 vaccines: Status report. Immunity, 52(4), 583-589. https://doi.org/10.1016/j.immuni.2020.03.007

Andersen, K. G., Rambaut, A., Lipkin, W. I., Holmes, E. C., \& Garry, R. F. (2020). The proximal origin of SARS-CoV-2. Nature Medicine, 26(4), 450-452. https://doi.org/10.1038/s41591-020-0820-9

Bhalla, N., Pan, Y., Yang, Z., \& Payam, A. F. (2020). Opportunities and challenges for biosensors and nanoscale analytical tools for pandemics: Covid-19. ACS Nano, 14(7), 7783-7807. https://doi.org/10.1021/acsnano.0c04421

Bisseux, M., Colombet, J., Mirand, A., Roque-Afonso, A.-M., Abravanel, F., Izopet, J., Archimbaud, C., Peigue-Lafeuille, H., Debroas, D., Bailly, J.-L., \& Henquell, C. (2018). Monitoring human enteric viruses in wastewater and relevance to infections encountered in the clinical setting: A one-year experiment in central France, 2014 to 2015. Eurosurveillance, 23(7), 17. https://doi.org/10.2807/1560-7917.ES.2018.23.7.17-00237

Bivins, A., North, D., Ahmad, A., Ahmed, W., Alm, E., Been, F., Bhattacharya, P., Bijlsma, L., Boehm, A. B., Brown, J., Buttiglieri, G., Calabro, V., Carducci, A., Castiglioni, S., Cetecioglu Gurol, Z., Chakraborty, S., Costa, F., Curcio, S., de los Reyes, F. L., \& Bibby, K. (2020). Wastewater-based epidemiology: Global collaborative to maximize contributions in the fight against covid-19. Environmental Science \& Technology, 54(13), 7754-7757. https://doi.org/10.1021/acs.est.0c02388

Bogler, A., Packman, A., Furman, A., Gross, A., Kushmaro, A., Ronen, A., Dagot, C., Hill, C., Vaizel-Ohayon, D., Morgenroth, E., Bertuzzo, E., Wells, G., Kiperwas, H. R., Horn, H., Negev, I., Zucker, I., Bar-Or, I., Moran-Gilad, J., Balcazar, J. L., \& Bar-Zeev, E. (2020). Rethinking wastewater risks and monitoring in light of the COVID-19 pandemic. Nature Sustainability, 3(12), 981-990. https://doi.org/10.1038/s41893-020-00605-2

Borsa, M., \& Mazet, J. M. (2020). Attacking the defence: SARS-CoV-2 can infect immune cells. Nature Reviews Immunology, 20(10), 592-592. https://doi.org/10.1038/s41577-020-00439-1

Cahill, N., \& Morris, D. (2020). Recreational waters - A potential transmission route for SARS-CoV-2 to humans? Science of The Total Environment, 740, 140122. https://doi.org/10.1016/j.scitotenv.2020.140122

Carducci, A., Federigi, I., Liu, D., Thompson, J. R., \& Verani, M. (2020). Making Waves: Coronavirus detection, presence and persistence in the water environment: State of the art and knowledge needs for public health. Water Research, 179, 115907. https://doi.org/10.1016/j.watres.2020.115907

Chavarria-Miró, G., Anfruns-Estrada, E., Guix, S., Paraira, M., Galofré, B., Sánchez, G., Pintó, R. M., \& Bosch, A. (2020). Sentinel surveillance of SARS CoV-2 in wastewater anticipates the occurrence of COVID-19 cases. MedRxiv, 2020.06.13.20129627. https://doi.org/10.1101/2020.06.13.20129627

Chen, L., Deng, C., Chen, X., Zhang, X., Chen, B., Yu, H., Qin, Y., Xiao, K., Zhang, H., \& Sun, X. (2020). Ocular manifestations and clinical characteristics of 535 cases of COVID-19 in Wuhan, China: A cross-sectional study. Acta Ophthalmologica, 98(8), e951-e959. https://doi.org/https://doi.org/10.1111/aos.14472

Choi, P. M., Tscharke, B. J., Donner, E., O’Brien, J. W., Grant, S. C., Kaserzon, S. L., Mackie, R., O’Malley, E., Crosbie, N. D., Thomas, K. V., \& Mueller, J. F. (2018). Wastewater-based epidemiology biomarkers: Past, present and future. TrAC Trends in Analytical Chemistry, 105, 453-469. https://doi.org/10.1016/j.trac.2018.06.004

Chu, D. K., Akl, E. A., Duda, S., Solo, K., Yaacoub, S., Schünemann, H. J., Chu, D. K., Akl, E. A., El-harakeh, A., Bognanni, A., Lotfi, T., Loeb, M., Hajizadeh, A., Bak, A., Izcovich, A., Cuello-Garcia, C. A., Chen, C., Harris, D. J., Borowiack, E., \& Schünemann, H. J. (2020). Physical distancing, face masks, and eye protection to prevent person-to-person transmission of SARS-CoV-2 and COVID-19: A systematic review and meta-analysis. The Lancet, 395(10242), 1973-1987. https://doi.org/10.1016/S0140-6736(20)31142-9

Cipollaro, L., Giordano, L., Padulo, J., Oliva, F., \& Maffulli, N. (2020). Musculoskeletal symptoms in SARS-CoV-2 (COVID-19) patients. Journal of Orthopaedic Surgery and Research, 15(1), 178, s13018-020-01702-w. https://doi.org/10.1186/s13018-020-01702-w

Corpuz, M. V. A., Buonerba, A., Vigliotta, G., Zarra, T., Ballesteros, F., Campiglia, P., Belgiorno, V., Korshin, G., \& Naddeo, V. (2020). Viruses in wastewater: Occurrence, abundance and detection methods. Science of The Total Environment, 745, 140910. https://doi.org/10.1016/j.scitotenv.2020.140910

Crits-Christoph, A., Kantor, R. S., Olm, M. R., Whitney, O. N., Al-Shayeb, B., Lou, Y. C., Flamholz, A., Kennedy, L. C., Greenwald, H., Hinkle, A., Hetzel, J., Spitzer, S., Koble, J., Tan, A., Hyde, F., Schroth, G., Kuersten, S., Banfield, J. F., \& Nelson, K. L. (2021). Genome sequencing of sewage detects regionally prevalent sars-cov-2 variants. MBio, 12(1), e02703-20,/mbio/12/1/mBio.02703-20.atom. https://doi.org/10.1128/mBio.02703-20

Curtis, K., Keeling, D., Yetka, K., Larson, A., \& Gonzalez, R. (2020). Wastewater SARS-CoV-2 concentration and loading variability from grab and 24-hour composite samples. In bioRxiv. https://doi.org/10.1101/2020.07.10.20150607

D’Aoust, P. M., Graber, T. E., Mercier, E., Montpetit, D., Alexandrov, I., Neault, N., Baig, A. T., Mayne, J., Zhang, X., Alain, T., Servos, M. R., Srikanthan, N., MacKenzie, M., Figeys, D., Manuel, D., Jüni, P., MacKenzie, A. E., \& Delatolla, R. (2021). Catching a resurgence: Increase in SARS-CoV-2 viral RNA 
identified in wastewater $48 \mathrm{~h}$ before COVID-19 clinical tests and $96 \mathrm{~h}$ before hospitalizations. Science of The Total Environment, $770,145319$. https://doi.org/10.1016/j.scitotenv.2021.145319

Daughton, C. G. (2018). Monitoring wastewater for assessing community health: Sewage Chemical-Information Mining (SCIM). Science of The Total Environment, 619-620, 748-764. https://doi.org/10.1016/j.scitotenv.2017.11.102

Daughton, C. G. (2020). Wastewater surveillance for population-wide Covid-19: The present and future. Science of The Total Environment, $736,139631$. https://doi.org/10.1016/j.scitotenv.2020.139631

Diao, B., Wang, C., Wang, R., Feng, Z., Tan, Y., Wang, H., Wang, C., Liu, L., Liu, Y., Liu, Y., Wang, G., Yuan, Z., Ren, L., Wu, Y., \& Chen, Y. (2020). Human Kidney is a Target for Novel Severe Acute Respiratory Syndrome Coronavirus 2 (SARS-CoV-2) Infection. Cold Spring Harbor Laboratory. https://doi.org/10.1101/2020.03.04.20031120

Ding, Z., Qian, H., Xu, B., Huang, Y., Miao, T., Yen, H.-L., Xiao, S., Cui, L., Wu, X., Shao, W., Song, Y., Sha, L., Zhou, L., Xu, Y., Zhu, B., \& Li, Y. (2021). Toilets dominate environmental detection of severe acute respiratory syndrome coronavirus 2 in a hospital. Science of The Total Environment, 753, 141710. https://doi.org/10.1016/j.scitotenv.2020.141710

Dolfing, J. (2020). The Importance of Sewage Archiving in Coronavirus Epidemiology and Beyond. Environmental Science \& Technology, 54(13), 77407741. https://doi.org/10.1021/acs.est.0c02972

Eliezer, M., Hautefort, C., Hamel, A.-L., Verillaud, B., Herman, P., Houdart, E., \& Eloit, C. (2020). Sudden and complete olfactory loss of function as a possible symptom of covid-19. JAMA Otolaryngology-Head \& Neck Surgery, 146(7), 674. https://doi.org/10.1001/jamaoto.2020.0832

Elsamadony, M., Fujii, M., Miura, T., \& Watanabe, T. (2021). Possible transmission of viruses from contaminated human feces and sewage: Implications for SARS-CoV-2. Science of The Total Environment, 755, 142575. https://doi.org/10.1016/j.scitotenv.2020.142575

Farkas, K., Mannion, F., Hillary, L. S., Malham, S. K., \& Walker, D. I. (2020). Emerging technologies for the rapid detection of enteric viruses in the aquatic environment. Current Opinion in Environmental Science \& Health, 16, 1-6. https://doi.org/10.1016/j.coesh.2020.01.007

Feng, W., Newbigging, A. M., Le, C., Pang, B., Peng, H., Cao, Y., Wu, J., Abbas, G., Song, J., Wang, D.-B., Cui, M., Tao, J., Tyrrell, D. L., Zhang, X.-E., Zhang, H., \& Le, X. C. (2020). Molecular Diagnosis of COVID-19: Challenges and Research Needs. Analytical Chemistry, 92(15), 10196-10209. https://doi.org/10.1021/acs.analchem.0c02060

Fernández-de-Mera, I. G., Rodríguez del-Río, F. J., Fuente, J., Pérez-Sancho, M., Hervás, D., Moreno, I., Domínguez, M., Domínguez, L., \& Gortázar, C. (2020). Detection of environmental SARS-CoV-2 RNA in a high prevalence setting in Spain. Transboundary and Emerging Diseases. https://doi.org/10.1111/tbed.13817

Foladori, P., Cutrupi, F., Segata, N., Manara, S., Pinto, F., Malpei, F., Bruni, L., \& La Rosa, G. (2020). SARS-CoV-2 from faeces to wastewater treatment: What do we know? A review. Science of The Total Environment, 743, 140444. https://doi.org/10.1016/j.scitotenv.2020.140444

Fongaro, G., Stoco, P. H., Souza, D. S. M., Grisard, E. C., Magri, M. E., Rogovski, P., Schörner, M. A., Barazzetti, F. H., Christoff, A. P., de Oliveira, L. F. V., Bazzo, M. L., Wagner, G., Hernández, M., \& Rodríguez-Lázaro, D. (2021). The presence of SARS-CoV-2 RNA in human sewage in Santa Catarina, Brazil, November 2019. Science of The Total Environment, 778, 146198. https://doi.org/10.1016/j.scitotenv.2021.146198

Furukawa, N. W., Brooks, J. T., \& Sobel, J. (2020). Evidence Supporting Transmission of Severe Acute Respiratory Syndrome Coronavirus 2 While Presymptomatic or Asymptomatic. Emerging Infectious Diseases, 26(7). https://doi.org/10.3201/eid2607.201595

Giri, B., Pandey, S., Shrestha, R., Pokharel, K., Ligler, F. S., \& Neupane, B. B. (2020). Review of analytical performance of COVID-19 detection methods. Analytical and Bioanalytical Chemistry, 413(1), 35-48. https://doi.org/10.1007/s00216-020-02889-x

Grunig, G., Durmus, N., \& Marsh, L. (2020). New Coronavirus (COVID-19) pandemic: Complexities resulting in a tragedy. In Preprints. https://doi.org/10.20944/preprints202004.0407.v2

Guo, T., Fan, Y., Chen, M., Wu, X., Zhang, L., He, T., Wang, H., Wan, J., Wang, X., \& Lu, Z. (2020). Cardiovascular implications of fatal outcomes of patients with coronavirus disease 2019(COVID-19). JAMA Cardiology, 5(7), 811. https://doi.org/10.1001/jamacardio.2020.1017

Gyawali, P., \& Hewitt, J. (2018). Detection of Infectious Noroviruses from Wastewater and Seawater Using PEMAXTM Treatment Combined with RTqPCR. Water, 10(7), 841. https://doi.org/10.3390/w10070841

Hamouda, M., Mustafa, F., Maraqa, M., Rizvi, T., \& Aly Hassan, A. (2021). Wastewater surveillance for SARS-CoV-2: Lessons learnt from recent studies to define future applications. Science of The Total Environment, 759, 143493. https://doi.org/10.1016/j.scitotenv.2020.143493

Hua, J., \& Shaw, R. (2020). Corona Virus (COVID-19) "Infodemic" and Emerging Issues through a Data Lens: The Case of China. International Journal of Environmental Research and Public Health, 17(7), 2309. https://doi.org/10.3390/ijerph17072309

Huang, W. E., Lim, B., Hsu, C.-C., Xiong, D., Wu, W., Yu, Y., Jia, H., Wang, Y., Zeng, Y., Ji, M., Chang, H., Zhang, X., Wang, H., \& Cui, Z. (2020). RTLAMP for rapid diagnosis of coronavirus SARS-CoV-2. Microbial Biotechnology, 13(4), 950-961. https://doi.org/https://doi.org/10.1111/1751-7915.13586

Hui, Q., Pan, Y., \& Yang, Z. (2020). Paper-based devices for rapid diagnostics and testing sewage for early warning of COVID-19 outbreak. Case Studies in Chemical and Environmental Engineering, 2, 100064. https://doi.org/10.1016/j.cscee.2020.100064

I. Ahmed, N., M. Elmahdy, E., K. Allayh, A., B. Mohamed, E.-C., A. Loutfy, S., Barakat, A., \& A. Ali, M. (2019). Prevalence of human polyomavirus and papillomavirus in wastewater and in stool of Egyptian patients. Egyptian Journal of Aquatic Biology and Fisheries, 23(2), 29-41. https://doi.org/10.21608/ejabf.2019.29237 
Izquierdo-Lara, R., Elsinga, G., Heijnen, L., Oude Munnink, B. B., Schapendonk, C. M. E., Nieuwenhuijse, D., Kon, M., Lu, L., Aarestrup, F. M., Lycett, S., Medema, G., Koopmans, M. P. G., \& de Graaf, M. (2020). Monitoring SARS-CoV-2 circulation and diversity through community wastewater sequencing. In bioRxiv. https://doi.org/10.1101/2020.09.21.20198838

Jahn, K., Dreifuss, D., Topolsky, I., Kull, A., Ganesanandamoorthy, P., Fernandez-Cassi, X., Bänziger, C., Stachler, E., Fuhrmann, L., Jablonski, K. P., Chen, C., Aquino, C., Stadler, T., Ort, C., Kohn, T., Julian, T. R., \& Beerenwinkel, N. (2021). Detection of SARS-CoV-2 variants in Switzerland by genomic analysis of wastewater samples. In bioRxiv. https://doi.org/10.1101/2021.01.08.21249379

Jeong, H. W., Kim, S.-M., Kim, H.-S., Kim, Y.-I., Kim, J. H., Cho, J. Y., Kim, S.-H., Kang, H., Kim, S.-G., Park, S.-J., Kim, E.-H., \& Choi, Y. K. (2020). Viable SARS-CoV-2 in various specimens from COVID-19 patients. Clinical Microbiology and Infection: The Official Publication of the European Society of Clinical Microbiology and Infectious Diseases, 26(11), 1520-1524. https://doi.org/10.1016/j.cmi.2020.07.020.

Jha, A. K., Semwal, N., \& Gargava, P. (2020). Issues and opportunities associated with SARS CoV-2 (COVID-19) virus detection in sewage. Journal of Indian Association for Environmental Management (JIAEM), 40(2), 49-51

Jiang, X., Luo, M., Zou, Z., Wang, X., Chen, C., \& Qiu, J. (2020). Asymptomatic SARS-CoV-2 infected case with viral detection positive in stool but negative in nasopharyngeal samples lasts for 42 days. Journal of Medical Virology, 92(10), 1807-1809. https://doi.org/https://doi.org/10.1002/jmv.25941

Jin, X., Lian, J.-S., Hu, J.-H., Gao, J., Zheng, L., Zhang, Y.-M., Hao, S.-R., Jia, H.-Y., Cai, H., Zhang, X.-L., Yu, G.-D., Xu, K.-J., Wang, X.-Y., Gu, J.-Q., Zhang, S.-Y., Ye, C.-Y., Jin, C.-L., Lu, Y.-F., Yu, X., ... Yang, Y. (2020). Epidemiological, clinical and virological characteristics of 74 cases of coronavirusinfected disease 2019 (COVID-19) with gastrointestinal symptoms. Gut, 69(6), 1002-1009. https://doi.org/10.1136/gutjnl-2020-320926

Jørgensen, A. C. U., Gamst, J., Hansen, L. V., Knudsen, I. I. H., \& Jensen, S. K. S. (2020). Eurofins Covid-19 Sentinel ${ }^{\mathrm{TM}}$ Wastewater Test Provide Early Warning of a potential COVID-19 outbreak. In bioRxiv. https://doi.org/10.1101/2020.07.10.20150573

Kang, M., Wei, J., Yuan, J., Guo, J., Zhang, Y., Hang, J., Qu, Y., Qian, H., Zhuang, Y., Chen, X., Peng, X., Shi, T., Wang, J., Wu, J., Song, T., He, J., Li, Y., \& Zhong, N. (2020). Probable evidence of fecal aerosol transmission of SARS-CoV-2 in a high-rise building. Annals of Internal Medicine, 173(12), 974-980. https://doi.org/10.7326/M20-0928

Kaplan, E. H., Wang, D., Wang, M., Malik, A. A., Zulli, A., \& Peccia, J. (2020). Aligning SARS-CoV-2 indicators via an epidemic model: application to hospital admissions and RNA detection in sewage sludge. Health Care Management Science. https://doi.org/10.1007/s10729-020-09525-1

Karthikeyan, S., Ronquillo, N., Belda-Ferre, P., Alvarado, D., Javidi, T., Longhurst, C. A., \& Knight, R. (2021). High-throughput wastewater SARS-CoV-2 detection enables forecasting of community infection dynamics in San Diego County. MSystems, 6(2). https://doi.org/10.1128/mSystems.00045-21

Kashi, A. H., De la Rosette, J., Amini, E., Abdi, H., Fallah-Karkan, M., \& Vaezjalali, M. (2020). Urinary viral shedding of COVID-19 and its clinical associations: A systematic review and meta-analysis of observational studies. Urology Journal, 17(5), 433-441. https://doi.org/10.22037/uj.v16i7.6248

Khan, S., Chen, L., Yang, C.-R., Raghuram, V., Khundmiri, S. J., \& Knepper, M. A. (2020). Does SARS-CoV-2 infect the kidney? Journal of the American Society of Nephrology: JASN, 31(12), 2746-2748. https://doi.org/10.1681/ASN.2020081229

Kitajima, M., Ahmed, W., Bibby, K., Carducci, A., Gerba, C. P., Hamilton, K. A., Haramoto, E., \& Rose, J. B. (2020). SARS-CoV-2 in wastewater: State of the knowledge and research needs. The Science of the Total Environment, 739(139076), 139076. https://doi.org/10.1016/j.scitotenv.2020.139076

Kumar, M., Joshi, M., Patel, A. K., \& Joshi, C. G. (2021). Unravelling the early warning capability of wastewater surveillance for COVID-19: A temporal study on SARS-CoV-2 RNA detection and need for the escalation. Environmental Research, 196(110946), 110946. https://doi.org/10.1016/j.envres.2021.110946

La Rosa, G., Iaconelli, M., Mancini, P., Bonanno Ferraro, G., Veneri, C., Bonadonna, L., Lucentini, L., \& Suffredini, E. (2020). First detection of SARS-CoV2 in untreated wastewaters in Italy. The Science of the Total Environment, 736(139652), 139652. https://doi.org/10.1016/j.scitotenv.2020.139652

La Rosa, G., Mancini, P., Bonanno Ferraro, G., Veneri, C., Iaconelli, M., Bonadonna, L., Lucentini, L., \& Suffredini, E. (2021). SARS-CoV-2 has been circulating in northern Italy since December 2019: Evidence from environmental monitoring. The Science of the Total Environment, 750(141711), 141711. https://doi.org/10.1016/j.scitotenv.2020.141711

Larsen, D. A., \& Wigginton, K. R. (2020). Tracking COVID-19 with wastewater. Nature Biotechnology, 38(10), 1151-1153. https://doi.org/10.1038/s41587020-0690-1

Lee, S., Kim, T., Lee, E., Lee, C., Kim, H., Rhee, H., Park, S. Y., Son, H.-J., Yu, S., Park, J. W., Choo, E. J., Park, S., Loeb, M., \& Kim, T. H. (2020). Clinical course and molecular viral shedding among asymptomatic and symptomatic patients with SARS-CoV-2 infection in a community treatment center in the Republic of Korea. JAMA Internal Medicine, 180(11), 1447. https://doi.org/10.1001/jamainternmed.2020.3862

Lesimple, A., Jasim, S. Y., Johnson, D. J., \& Hilal, N. (2020). The role of wastewater treatment plants as tools for SARS-CoV-2 early detection and removal. Journal of Water Process Engineering, 38(101544), 101544. https://doi.org/10.1016/j.jwpe.2020.101544

Li, W., Su, Y.-Y., Zhi, S.-S., Huang, J., Zhuang, C.-L., Bai, W.-Z., Wan, Y., Meng, X.-R., Zhang, L., Zhou, Y.-B., Luo, Y.-Y., Ge, S.-X., Chen, Y.-K., \& Ma, Y. (2020). Virus shedding dynamics in asymptomatic and mildly symptomatic patients infected with SARS-CoV-2. Clinical Microbiology and Infection: The Official Publication of the European Society of Clinical Microbiology and Infectious Diseases, 26(11), 1556.e1-1556.e6. https://doi.org/10.1016/j.cmi.2020.07.008

Lu, D., Zhu, D. Z., Gan, H., Yao, Z., Fu, Q., \& Zhang, X. (2021). Prospects and challenges of using electrochemical immunosen sors as an alternative detection method for SARS-CoV-2 wastewater-based epidemiology. The Science of the Total Environment, $777(146239)$, 146239. https://doi.org/10.1016/j.scitotenv.2021.146239

Pecson, B. M., Darby, E., Haas, C. N., Amha, Y. M., Bartolo, M., Danielson, R., Dearborn, Y., Di Giovanni, G., Ferguson, C., Fevig, S., Gaddis, E., Gray, D., Lukasik, G., Mull, B., Olivas, L., Olivieri, A., Qu, Y., \& SARS-CoV-2 Interlaboratory Consortium. (2021). Reproducibility and sensitivity of 36 methods to 
quantify the SARS-CoV-2 genetic signal in raw wastewater: findings from an interlaboratory methods evaluation in the U.S. Environmental Science: Water Research \& Technology, 7(3), 504-520. https://doi.org/10.1039/D0EW00946F

Mainardi, P. H., \& Bidoia, E. D. (2021). A importância do monitoramento do SARS-CoV-2 em redes de esgoto e estações de tratamento de águas residuárias / The importance of monitoring the SARS-CoV-2 in sewage networks and wastewater treatment plants. Brazilian Journal of Health Review, 4(2), 5051-5066. https://doi.org/10.34119/bjhrv4n2-083

Mao, K., Zhang, H., \& Yang, Z. (2020b). An integrated biosensor system with mobile health and wastewater-based epidemiology (iBMW) for COVID-19 pandemic. Biosensors \& Bioelectronics, 169(112617), 112617. https://doi.org/10.1016/j.bios.2020.112617

Mao, K., Zhang, K., Du, W., Ali, W., Feng, X., \& Zhang, H. (2020a). The potential of wastewater-based epidemiology as surveillance and early warning of infectious disease outbreaks. Current Opinion in Environmental Science \& Health, 17, 1-7. https://doi.org/10.1016/j.coesh.2020.04.006

Martin, J., Klapsa, D., Wilton, T., Zambon, M., Bentley, E., Bujaki, E., Fritzsche, M., Mate, R., \& Majumdar, M. (2020). Tracking SARS-CoV-2 in sewage: Evidence of changes in virus variant predominance during COVID-19 pandemic. Viruses, 12(10), 1144. https://doi.org/10.3390/v12101144

Medema, G., Been, F., Heijnen, L., \& Petterson, S. (2020b). Implementation of environmental surveillance for SARS-CoV-2 virus to support public health decisions: Opportunities and challenges. Current Opinion in Environmental Science \& Health, 17, 49-71. https://doi.org/10.1016/j.coesh.2020.09.006

Medema, G., Heijnen, L., Elsinga, G., Italiaander, R., \& Brouwer, A. (2020a). Presence of SARS-Coronavirus-2 RNA in sewage and correlation with reported COVID-19 prevalence in the early stage of the epidemic in the Netherlands. Environmental Science \& Technology Letters, 7(7), 511-516. https://doi.org/10.1021/acs.estlett.0c00357

Melvin, R. G., Chaudhry, N., Georgewill, O., Freese, R., \& Simmons, G. E. (2021). Predictive power of SARS-CoV-2 wastewater surveillance for diverse populations across a large geographical range. MedRxiv. https://doi.org/10.1101/2021.01.23.21250376

Messina, S. (2020). Monitoring Human Waste. Voices in Bioethics, Vol 6 (2020). https://doi.org/10.7916/VIB.V6I.6406

Michael-Kordatou, I., Karaolia, P., \& Fatta-Kassinos, D. (2020). Sewage analysis as a tool for the COVID-19 pandemic response and management: the urgent need for optimised protocols for SARS-CoV-2 detection and quantification. Journal of Environmental Chemical Engineering, 8(5), 104306. https://doi.org/10.1016/j.jece.2020.104306

Morawska, L., \& Cao, J. (2020). Airborne transmission of SARS-CoV-2: The world should face the reality. Environment International, 139(105730), 105730. https://doi.org/10.1016/j.envint.2020.105730

Mouchtouri, V. A., Koureas, M., Kyritsi, M., Vontas, A., Kourentis, L., Sapounas, S., Rigakos, G., Petinaki, E., Tsiodras, S., \& Hadjichristodoulou, C. (2020). Environmental contamination of SARS-CoV-2 on surfaces, air-conditioner and ventilation systems. International Journal of Hygiene and Environmental Health, 230(113599), 113599. https://doi.org/10.1016/j.ijheh.2020.113599

Nabi, G., Siddique, R., \& Khan, S. (2020). Detecting viral outbreaks in future using enhanced environmental surveillance. Environmental Research, 188(109731), 109731. https://doi.org/10.1016/j.envres.2020.109731

Nemudryi, A., Nemudraia, A., Wiegand, T., Surya, K., Buyukyoruk, M., Cicha, C., Vanderwood, K. K., Wilkinson, R., \& Wiedenheft, B. (2020). Temporal detection and phylogenetic assessment of SARS-CoV-2 in municipal wastewater. Cell Reports Medicine, 100098, 100098. https://doi.org/10.1016/j.xcrm.2020.100098

O’Brien, E., Nakyazze, J., Wu, H., Kiwanuka, N., Cunningham, W., Kaneene, J. B., \& Xagoraraki, I. (2017). Viral diversity and abundance in polluted waters in Kampala, Uganda. Water Research, 127, 41-49. https://doi.org/10.1016/j.watres.2017.09.063

Orive, G., Lertxundi, U., \& Barcelo, D. (2020). Early SARS-CoV-2 outbreak detection by sewage-based epidemiology. The Science of the Total Environment, 732(139298), 139298. https://doi.org/10.1016/j.scitotenv.2020.139298

Park, S.-K., Lee, C.-W., Park, D.-I., Woo, H.-Y., Cheong, H. S., Shin, H. C., Ahn, K., Kwon, M.-J., \& Joo, E.-J. (2020). Detection of SARS-CoV-2 in fecal samples from patients with asymptomatic and mild COVID-19 in Korea. Clinical Gastroenterology and Hepatology: The Official Clinical Practice Journal of the American Gastroenterological Association. https://doi.org/10.1016/j.cgh.2020.06.005

Patel, J. (2020). Viability of SARS-CoV-2 in faecal bio-aerosols. Colorectal Disease, 22(9), 1022-1022. https://doi.org/10.1111/codi.15181

Patel, K. P., Vunnam, S. R., Patel, P. A., Krill, K. L., Korbitz, P. M., Gallagher, J. P., Suh, J. E., \& Vunnam, R. R. (2020). Transmission of SARS-CoV-2: an update of current literature. European Journal of Clinical Microbiology \& Infectious Diseases: Official Publication of the European Society of Clinical Microbiology, 39(11), 2005-2011. https://doi.org/10.1007/s10096-020-03961-1

Patel, M., Chaubey, A. K., Pittman, C. U., Jr, Mlsna, T., \& Mohan, D. (2021). Coronavirus (SARS-CoV-2) in the environment: Occurrence, persistence, analysis in aquatic systems and possible management. The Science of the Total Environment, $765(142698)$, 142698. https://doi.org/10.1016/j.scitotenv.2020.142698

Peccia, J., Zulli, A., Brackney, D. E., Grubaugh, N. D., Kaplan, E. H., Casanovas-Massana, A., Ko, A. I., Malik, A. A., Wang, D., Wang, M., Warren, J. L., Weinberger, D. M., Arnold, W., \& Omer, S. B. (2020). Measurement of SARS-CoV-2 RNA in wastewater tracks community infection dynamics. Nature Biotechnology, 38(10), 1164-1167. https://doi.org/10.1038/s41587-020-0684-z

Pérez-Cataluña, A., Chiner-Oms, Á., Cuevas-Ferrando, E., Díaz-Reolid, A., Falcó, I., Randazzo, W., Girón-Guzmán, I., Allende, A., Bracho, M. A., Comas, I., \& Sánchez, G. (2021). Detection of genomic variants of SARS-CoV-2 circulating in wastewater by high-throughput sequencing. In bioRxiv. https://doi.org/10.1101/2021.02.08.21251355

Pezzini, A., \& Padovani, A. (2020). Lifting the mask on neurological manifestations of COVID-19. Nature Reviews. Neurology, 16(11), 636-644. https://doi.org/10.1038/s41582-020-0398-3 
Polo, D., Quintela-Baluja, M., Corbishley, A., Jones, D. L., Singer, A. C., Graham, D. W., \& Romalde, J. L. (2020). Making waves: Wastewater-based epidemiology for COVID-19 - approaches and challenges for surveillance and prediction. Water Research, 186(116404), 116404. https://doi.org/10.1016/j.watres.2020.116404

Qian, Q., Fan, L., Liu, W., Li, J., Yue, J., Wang, M., Ke, X., Yin, Y., Chen, Q., \& Jiang, C. (2020). Direct evidence of active SARS-CoV-2 replication in the intestine. Clinical Infectious Diseases: An Official Publication of the Infectious Diseases Society of America. https://doi.org/10.1093/cid/ciaa925

Quilliam, R. S., Weidmann, M., Moresco, V., Purshouse, H., O’Hara, Z., \& Oliver, D. M. (2020). COVID-19: The environmental implications of shedding SARS-CoV-2 in human faeces. Environment International, 140, 105790. https://doi.org/10.1016/j.envint.2020.105790

Randazzo, W., Piqueras, J., Evtoski, Z., Sastre, G., Sancho, R., Gonzalez, C., \& Sánchez, G. (2019). Interlaboratory comparative study to detect potentially infectious human Enteric viruses in influent and effluent waters. Food and Environmental Virology, 11(4), 350-363. https://doi.org/10.1007/s12560-019$09392-2$

Randazzo, W., Truchado, P., Cuevas-Ferrando, E., Simón, P., Allende, A., \& Sánchez, G. (2020). SARS-CoV-2 RNA in wastewater anticipated COVID-19 occurrence in a low prevalence area. Water Research, 181(115942), 115942. https://doi.org/10.1016/j.watres.2020.115942

Saguti, F., Magnil, E., Enache, L., Churqui, M. P., Johansson, A., Lumley, D., Davidsson, F., Dotevall, L., Mattsson, A., Trybala, E., Lagging, M., Lindh, M., Gisslén, M., Brezicka, T., Nyström, K., \& Norder, H. (2021). Surveillance of wastewater revealed peaks of SARS-CoV-2 preceding those of hospitalized patients with COVID-19. Water Research, 189(116620), 116620. https://doi.org/10.1016/j.watres.2020.116620

Sah, R., Pokhrel, N., Fathah, Z., Ozaki, A., Bhandari, D., Kotera, Y., Shah, N. P., Sigdel, S., Vora, K. S., Natesan, S. K., Patel, S. K., Tiwari, R., Malik, Y. S., Yatoo, M. I., Rodriguez-Morales, A. J., \& Dhama, K. (2020). SARS-CoV-2 / COVID-19: Salient facts and strategies to combat ongoing pandemic. Journal of Pure \& Applied Microbiology, 14(3), 1663-1674. https://doi.org/10.22207/JPAM.14.3.04

Setti, L., Passarini, F., De Gennaro, G., Barbieri, P., Perrone, M. G., Borelli, M., Palmisani, J., Di Gilio, A., Piscitelli, P., \& Miani, A. (2020). Airborne transmission route of COVID-19: Why 2 meters/6 feet of inter-personal distance could not be enough. International Journal of Environmental Research and Public Health, 17(8), 2932. https://doi.org/10.3390/ijerph17082932

Sims, N., \& Kasprzyk-Hordern, B. (2020). Future perspectives of wastewater-based epidemiology: Monitoring infectious disease spread and resistance to the community level. Environment International, 139(105689), 105689. https://doi.org/10.1016/j.envint.2020.105689

Stadler, L. B., Ensor, K. B., Clark, J. R., Kalvapalle, P., LaTurner, Z. W., Mojica, L., Terwilliger, A., Zhuo, Y., Ali, P., Avadhanula, V., Bertolusso, R., Crosby, T., Hernandez, H., Hollstein, M., Weesner, K., Zong, D. M., Persse, D., Piedra, P. A., Maresso, A. W., \& Hopkins, L. (2020). Wastewater analysis of SARS-CoV-2 as a predictive metric of positivity rate for a major metropolis. In bioRxiv. https://doi.org/10.1101/2020.11.04.20226191

Sun, P., Qie, S., Liu, Z., Ren, J., Li, K., \& Xi, J. (2020). Clinical characteristics of hospitalized patients with SARS-CoV-2 infection: A single arm metaanalysis. Journal of Medical Virology, 92(6), 612-617. https://doi.org/10.1002/jmv.25735

Thompson, J. R., Nancharaiah, Y. V., Gu, X., Lee, W. L., Rajal, V. B., Haines, M. B., Girones, R., Ng, L. C., Alm, E. J., \& Wuertz, S. (2020). Making waves: Wastewater surveillance of SARS-CoV-2 for population-based health management. Water Research, 184(116181), 116181. https://doi.org/10.1016/j.watres.2020.116181

Tymm, C., Zhou, J., Tadimety, A., Burklund, A., \& Zhang, J. X. J. (2020). Scalable COVID-19 detection enabled by lab-on-chip biosensors. Cellular and Molecular Bioengineering, 13(4), 1-17. https://doi.org/10.1007/s12195-020-00642-Z

Vallejo, J. A., Rumbo-Feal, S., Conde-Pérez, K., López-Oriona, Á., Tarrío, J., Reif, R., Ladra, S., Rodiño-Janeiro, B. K., Nasser, M., Cid, Á., Veiga, M. C., Acevedo, A., Lamora, C., Bou, G., Cao, R., \& Poza, M. (2020). Highly predictive regression model of active cases of COVID-19 in a population by screening wastewater viral load. In bioRxiv. https://doi.org/10.1101/2020.07.02.20144865

Wei, W. E., Li, Z., Chiew, C. J., Yong, S. E., Toh, M. P., \& Lee, V. J. (2020). Presymptomatic transmission of SARS-CoV-2 - Singapore, January 23-March 16, 2020. MMWR. Morbidity and Mortality Weekly Report, 69(14), 411-415. https://doi.org/10.15585/mmwr.mm6914e1

Weidhaas, J., Aanderud, Z. T., Roper, D. K., VanDerslice, J., Gaddis, E. B., Ostermiller, J., Hoffman, K., Jamal, R., Heck, P., Zhang, Y., Torgersen, K., Laan, J. V., \& LaCross, N. (2021). Correlation of SARS-CoV-2 RNA in wastewater with COVID-19 disease burden in sewersheds. The Science of the Total Environment, 775(145790), 145790. https://doi.org/10.1016/j.scitotenv.2021.145790

World Health Organization (2020c). Water, sanitation, hygiene, and waste management for SARS-CoV-2, the virus that causes COVID-19: interim guidance, 29 July 2020. World Health Organization

World Health Organization (2020b). WHO Coronavirus Disease (COVID-19) Dashboard. World Health Organization. https://covid19.who.int/

World Health Organization (2020a). WHO Director-General's opening remarks at the media briefing on COVID-19-11 March 2020. World Health Organization

Wurtzer, S., Waldman, P., Levert, M., Mouchel, J. M., Gorgé, O., Boni, M., Maday, Y., Marechal, V., Moulin, L., \& OBEPINE consortium. (2021). Monitoring the propagation of SARS CoV2 variants by tracking identified mutation in wastewater using specific RT-qPCR. In bioRxiv. https://doi.org/10.1101/2021.03.10.21253291

Xiao, F., Sun, J., Xu, Y., Li, F., Huang, X., Li, H., Zhao, J., Huang, J., \& Zhao, J. (2020). Infectious SARS-CoV-2 in feces of patient with severe COVID-19. Emerging Infectious Diseases, 26(8), 1920-1922. https://doi.org/10.3201/eid2608.200681

Xie, C., Zhao, H., Li, K., Zhang, Z., Lu, X., Peng, H., Wang, D., Chen, J., Zhang, X., Wu, D., Gu, Y., Yuan, J., Zhang, L., \& Lu, J. (2020). The evidence of indirect transmission of SARS-CoV-2 reported in Guangzhou, China. BMC Public Health, 20(1), 1202. https://doi.org/10.1186/s12889-020-09296-y 
Research, Society and Development, v. 10, n. 5, e45910515219, 2021

(CC BY 4.0) | ISSN 2525-3409 | DOI: http://dx.doi.org/10.33448/rsd-v10i5.15219

Xu, X.-W., Wu, X.-X., Jiang, X.-G., Xu, K.-J., Ying, L.-J., Ma, C.-L., Li, S.-B., Wang, H.-Y., Zhang, S., Gao, H.-N., Sheng, J.-F., Cai, H.-L., Qiu, Y.-Q., \& Li, L.-J. (2020). Clinical findings in a group of patients infected with the 2019 novel coronavirus (SARS-Cov-2) outside of Wuhan, China: retrospective case series. BMJ (Clinical Research Ed.), 368, m606. https://doi.org/10.1136/bmj.m606

Yang, X., Yu, Y., Xu, J., Shu, H., Xia, J., Liu, H., Wu, Y., Zhang, L., Yu, Z., Fang, M., Yu, T., Wang, Y., Pan, S., Zou, X., Yuan, S., \& Shang, Y. (2020). Clinical course and outcomes of critically ill patients with SARS-CoV-2 pneumonia in Wuhan, China: a single-centered, retrospective, observational study. The Lancet. Respiratory Medicine, 8(5), 475-481. https://doi.org/10.1016/S2213-2600(20)30079-5

Yaniv, K., Ozer, E., Plotkin, N., Bhandarkar, N. S., \& Kushmaro, A. (2021). RT-qPCR assay for detection of British (B.1.1.7) and South Africa (B.1.351) variants of SARS-CoV-2. MedRxiv 2021:2021.02.25.21252454. https://doi.org/10.1101/2021.02.25.21252454

Zhang, D., Ling, H., Huang, X., Li, J., Li, W., Yi, C., Zhang, T., Jiang, Y., He, Y., Deng, S., Zhang, X., Wang, X., Liu, Y., Li, G., \& Qu, J. (2020b). Potential spreading risks and disinfection challenges of medical wastewater by the presence of Severe Acute Respiratory Syndrome Corona virus 2 (SARS-CoV-2) viral RNA in septic tanks of Fangcang Hospital. The Science of the Total Environment, 741(140445), 140445. https://doi.org/10.1016/j.scitotenv.2020.140445

Zhang, D., Yang, Y., Huang, X., Jiang, J., Li, M., Zhang, X., Ling, H., Li, J., Liu, Y., Li, G., Li, W., Yi, C., Zhang, T., Jiang, Y., Xiong, Y., Hu, Z., Wang, X., Deng, S., Zhao, P., \& Qu, J. (2020a). SARS-CoV-2 spillover into hospital outdoor environments. In bioRxiv. https://doi.org/10.1101/2020.05.12.20097105

Zu, Z. Y., Jiang, M. D., Xu, P. P., Chen, W., Ni, Q. Q., Lu, G. M., \& Zhang, L. J. (2020). Coronavirus disease 2019 (COVID-19): A perspective from China. Radiology, 296(2), E15-E25. https://doi.org/10.1148/radiol.2020200490 